\title{
Avian recolonization of unrestored and restored bogs in Eastern Canada
}

\author{
André Desrochers Département des sciences du bois et de la forêt, Université Laval, Québec, Canada \\ Line Rochefort Peatland Ecology Research Group and Centre for Northern Studies, Université Laval, Québec, \\ Canada
}

Over the last several decades, peat has been extracted from bogs of temperate, populated regions of Eastern Canada, leaving large areas devoid of vegetation if unrestored. For the last 25 years, projects have been conducted in these regions to re-establish vegetation and facilitate recolonization by wildlife. We tested whether vegetation structure and bird species assemblages 10 to 20 years post extraction differ among natural, unrestored and restored bogs at the scales of individual sites and entire bogs. We conducted bird counts and vegetation surveys between 1993 and 2019, using both point counts (309 sites) and Autonomous Recording Units (80 sites). According to our vegetation surveys, restoration of sites that were previously used for peat harvesting accelerated the establishment of Sphagnum and herbaceous strata, but ericaceous and tree strata were unaffected over a 17-year period. None of the bird species with large home ranges were associated specifically to natural, unrestored, or restored areas at the bog level. Bird species diversity was similar in restored and natural sites, but lower in unrestored sites. Alder Flycatcher and American Goldfinch occupied restored and unrestored sites more frequently than natural sites, independent of the number of years post extraction. Occupancy of restored sites by Palm and Yellow-rumped Warblers increased over the years, reaching levels similar to those in natural sites 20 years after restoration was implemented. Occupancy of restored sites by Song and Savannah sparrows increased from 1993-2019 and diverged from their declining occupancy of natural sites. Species assemblages of restored and unrestored sites differed significantly from those of natural sites soon after peat extraction ceased or post restoration. But assemblages from restored and unrestored sites became progressively similar to those of natural sites during the first 20 years, especially in restored sites. We conclude that bird species assemblages of restored bog sites are converging toward those of natural sites, and that restoration provides novel habitats for regionally declining species, e.g., Savannah Sparrows.

Keywords: Peatland, Ecological Restoration, Boreal, Ornithology, Occupancy, Species Diversity, Habitat Selection, Autonomous Recording Units

\section{Introduction}

Sphagnum-dominated peatlands, or bogs, sometimes dominate boreal and subarctic landscapes (Gorham, 1990) and extend south to temperate latitudes, with increasing isolation and distinctiveness from landscapes (Brewer, 1967; Calmé and Desrochers, 2000; Poulin and Pellerin, 2001). In temperate, populated regions, they are often drained for the extraction of peat and other uses. In Eastern Canada, horticultural peat extraction has occurred for nearly a century, starting with small-scale manual extraction by blocks, which was gradually replaced by large-scale extraction with vacuum-harvesters pulled by tractors (Girard et al., 2002). A small proportion of peatlands has been used for peat extraction in boreal Canada $(<0.03 \%$; CSPMA (2014)), but undisturbed peatlands, especially large ones, have become rare in populated areas of Eastern Canada (Pellerin, 2003; Poulin et al., 2016). Since the 1990s, wetland ecologists have been aware of the poten- 
tial impact of peat extraction on regional biodiversity, and the potential of ecological restoration (Wheeler and Shaw, 1995; Gorham and Rochefort, 2003). During the same period, the peat moss industry collectively decided to develop ecological restoration methods to facilitate the return to peat-accumulating ecosystems, with associated flora and fauna (Rochefort, 2000).

Wetland restoration is challenging, especially in colder climates where ecosystem processes are slower (Moreno-Mateos et al., 2012). Early on, some researchers thought that bogs formerly subjected to peat extraction may revert to peat-accumulating ecosystems without active restoration (Green, 1983; Smart et al., 1989; Famous et al., 1995). After decades of bog restoration and comparisons with unrestored peat-extracted bogs, this hypothesis is no longer supported (Poulin et al., 2005; Lavoie et al., 2003) and consequently ecological restoration of peat-extracted bogs is taking place in several northern countries (Andersen et al., 2017; Chimner et al., 2017; Karofeld et al., 2016). But we do not know yet whether restoration can produce wildlife species assemblages similar to those of natural sites.

Measuring the success of ecological restoration is not a trivial matter, and should fulfill several criteria, some of which include reaching a desired species diversity, assemblage and indigenous species (Prach et al., 2019). The return of plant species assemblages and vegetation structure has been the focus of earlier ecological restoration work (Young, 2000; Hugron et al., 2020), some of which was motivated by the 'if you build it, they will come' assumption (Palmer et al., 1997). Restoring vegetation may be necessary, but insufficient however, for a lasting recolonization of restored sites by wildlife, as exemplified by several studies (e.g., Cross et al., 2019). In the case of bogs, previous work by Desrochers et al. (1998) showed substantial differences among bird species assemblages in unrestored vs. natural sites, but their work was based only on surveys spanning 3 years, at a time when bog restoration was in its infancy, with few recovery years since restoration.

This study documents the re-establishment of vegetation and associated breeding birds in Québec and New Brunswick, from 1993 to 2019. More specifically, we compared vegetation cover and site occupancy by songbirds between natural, unrestored, and restored sites. Additionally, we tested whether the occupancy of species with large home ranges was associated to aggregated areas of undisturbed, unrestored and restored sites at the scale of entire bogs.

\section{Study Area and Methods}

We sampled bird populations in 38 open raised bogs of Québec and New Brunswick, sometimes hundreds of kilometers apart (Fig. 1). Each year of data collection, we sampled natural, unrestored (without management post extraction), and restored sites in most of the bogs. Throughout this paper, we define sites as specific, contiguous areas of bogs with a homogeneous class (natural, restored, etc.) We assume that our sampling approach led to no major confounding effects of regional and temporal variation among bogs.

\section{Bird Point Counts}

We performed 1659 point counts at 309 sites in 1993, 1996, 1999, 2002, 2005, and 2011, in the absence of strong wind or rain (Table 1). Point counts were separated by $>200 \mathrm{~m}$ and performed between 20 May and 15 July. Each point count site was sampled on 1 to 5 occasions within a given breeding season. Point count duration was $10 \mathrm{~min}$ in the mornings and $5 \mathrm{~min}$ in the evenings, with the exception of 15-min point counts with playbacks of alarm and mobbing calls (details in Corbani et al. (2014)), which were performed in 2011 for a separate study. All 12 observers who conducted point counts had $>5 \mathrm{y}$ of birding experience and were assigned natural, unrestored and restored sites. We assume that variation among observers did not create bias. 
bioRxiv preprint doi: https://doi.org/10.1101/2021.11.26.470119; this version posted November 27, 2021. The copyright holder for this preprint (which was not certified by peer review) is the author/funder, who has granted bioRxiv a license to display the preprint in perpetuity. It is made available under aCC-BY-NC-ND 4.0 International license.

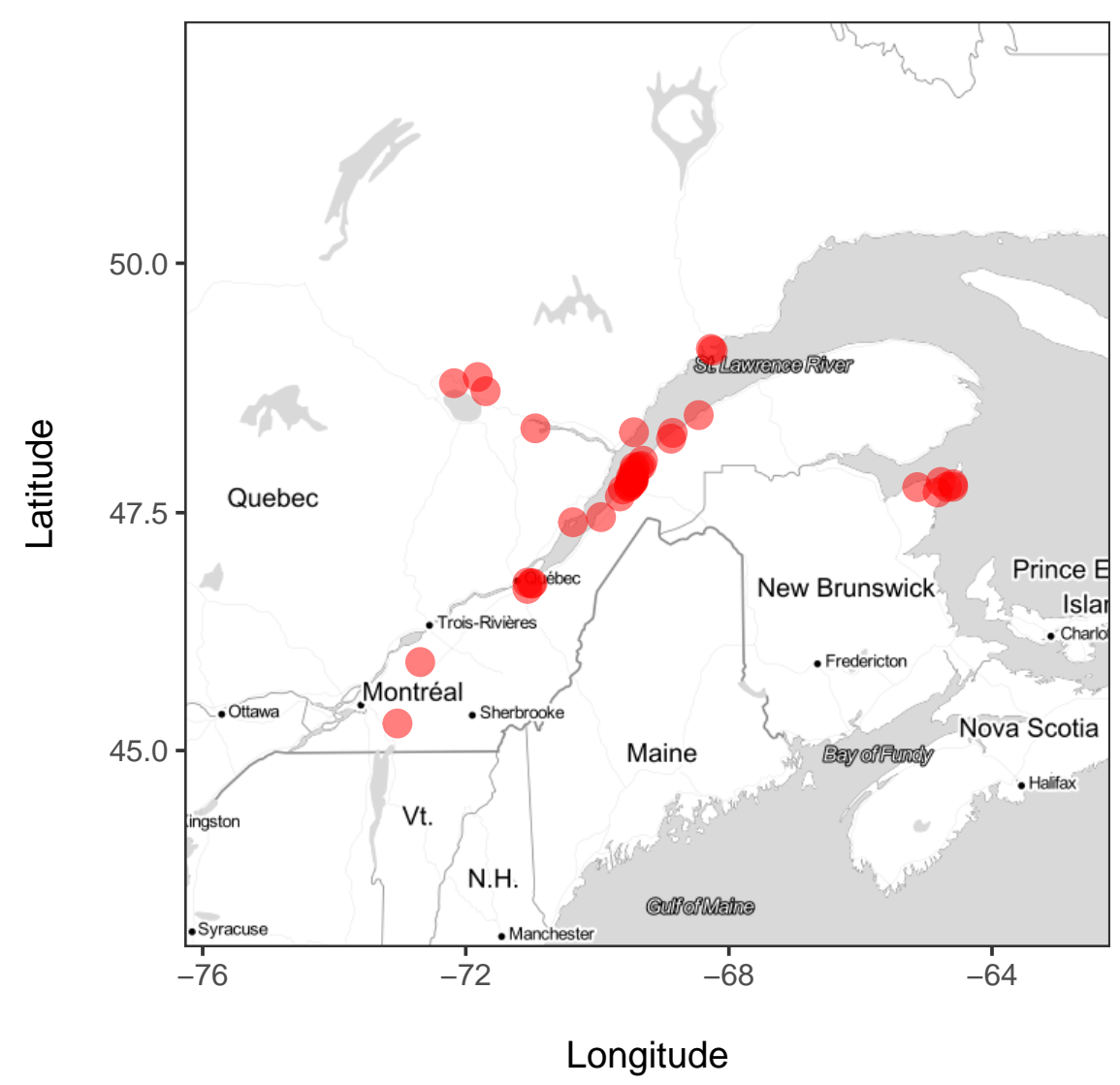

Figure 1: Study area. 
Table 1: Numbers of bird surveys by method and time of day.

\begin{tabular}{|c|c|c|c|c|c|c|c|c|c|c|}
\hline \multirow[b]{2}{*}{ Protocol } & \multirow[b]{2}{*}{ Time } & \multirow[b]{2}{*}{ Minutes } & \multicolumn{8}{|c|}{ Year } \\
\hline & & & 1993 & 1996 & 1999 & 2002 & 2005 & 2011 & 2018 & 2019 \\
\hline \multirow{4}{*}{ Passive Point Count } & \multirow{2}{*}{ Evening } & 5 & 39 & & & & & & & \\
\hline & & 10 & 23 & & & & & & & \\
\hline & \multirow{4}{*}{ Morning } & 5 & 17 & & & & & & & \\
\hline & & 10 & 376 & 96 & 210 & 203 & 325 & 142 & & \\
\hline \multirow{2}{*}{ Point Count with Playback } & & 10 & & & & & & 112 & & \\
\hline & & 15 & & & & & & 116 & & \\
\hline \multirow{2}{*}{ Autonomous Recording Unit } & Evening & 5 & & & & & & & 51 & 45 \\
\hline & Morning & 5 & & & & & & & 188 & 175 \\
\hline
\end{tabular}

\section{Recordings}

In 2018 and 2019, we deployed Wildlife Acoustics Song Meters (models SM3 and SM4; Wildlife Acoustics Inc., Concord, MA, USA) on 80 sites separated by $>200 \mathrm{~m}$ (Table 1). We programmed each of those Autonomous Recording Units (ARUs) to record one 5-minute sample per hour during deployments that lasted between 0.4 and $26 \mathrm{~d}$ (mean = 7.8 d). After deleting samples with excessive noise due to wind, rain, or malfunction, for each site, each year, we sampled two to five 5-min samples between 4:00 - 9:00 EDT (mean $=4.5$ samples) on different days, and one to four samples between 19:00 - 22:00 EDT (mean = 1.2 samples), also on different days. Each recording was encoded on two channels with a $24 \mathrm{KHz}$ sampling rate and a 16 bit resolution. Each recording sample was listened to with headphones by A.D. and all species heard were transcribed into an eBird list (Sullivan et al., 2009).

\section{Bog land cover}

We measured the temporal evolution of land cover in bogs from a combination of aerial and satellite images taken throughout the study period, as well as GPS surveys. All spatial data were recorded as adjacent polygons and incorporated in an ArcGIS geodatabase (ESRI, 2019) using a decimal degree, WGS84 (EPSG 4326) projection. We ascribed one of the following categories to each polygon: natural, peat-extracted, unrestored, restored, pond. Sites not corresponding to those categories were ignored. We estimated the year of the ending of peat extraction and restoration for each polygon for which one of those categories occurred at least once. We updated bog land cover categories for each survey year. Sampling plots for vegetation and birds (see below) were characterized as unrestored (peat extracted), restored or natural only if $>50 \%$ of their area corresponded to one of those categories. We retained only sites unrestored or restored 10 to $20 \mathrm{y}$ before the surveys, because older unrestored sites had no restored counterparts with similar ages. We assumed that restored and unrestored sites less than $10 \mathrm{y}$ old were not sufficiently different to greatly influence bird occupancy. 


\section{Vegetation surveys}

Prior to each point count, observers estimated the percent cover of bare peat, Sphagnum, herbaceous plants, ericaceous plants, shrubs $(<5 \mathrm{~m})$ and trees, all on circular plots delimited with surveying flags and $<100 \mathrm{~m}$ from the observer. Strata sometimes overlapped, leading to total cover exceeding $100 \%$. Standard deviations among estimates on the same year for single sites ranged from $5.7-17.8 \%$. We did not perform vegetation surveys in 2018 or 2019.

\section{Statistical analysis}

Traditional analyses of species occurrences were performed without accounting for imperfect species detection, e.g. in our former study of peatland birds (Desrochers et al., 1998). This basic approach not only precludes actual estimate of true site occupancy, but it may lead to biases if the detection process is dependent on factors associated with sampling time or location (Mazerolle et al., 2005). Repeated bird surveys at the same sites during a single breeding season, as in the present study, allow the estimation of detection probabilities, given that species are often encountered at certain surveys but not others. Assuming that species were invariably present or absent at given sites during the entire season each year (the closure assumption), it is possible to estimate detection probabilities and adjust estimates of site occupation accordingly (MacKenzie et al., 2002). Mackenzie et al's approach use maximum-likelihood estimation to simultaneously model detection probabilities against covariates that may affect detection (time of day, etc.), and occupancy itself, against site characteristics.

We measured site occupancy by birds by accounting for imperfect detection with Mackenzie et al's (2002) occupancy modelling. We conducted analyses separately for species with small home ranges (most songbirds) and species with large home ranges or usually detectable from distances exceeding $100 \mathrm{~m}$ (raptors, swallows, shorebirds, etc.). We considered species as significantly responding to natural, unrestored or restored sites when the weight of evidence of the null model was less than $5 \%$ divided by the number of species tested, to maintain Type I error rate (false positives) at $\alpha=5 \%$ despite multiple testing.

\section{Birds with small home ranges}

We compared bird species observed from natural, unrestored and restored sites, with two approaches. First, we examined species diversity by computing species accumulation curves (Soberón and Llorente, 1993). Given the multiple ways to obtain cumulative species numbers (depending on the ordering of sites), we used a bootstrap procedure (Efron, 1982), i.e we sampled $n$ sites with replacement, each 100 times, and computed the mean and standard error of the number of species for each $n$. We used a maximum $n$ of 22 sites, because that was the number of sites of the least sampled site category (restored). Species diversities from 22 sites were compared with a randomization test, i.e. by comparing the observed differences to a random distribution of 10,000 simulated differences from shuffled site categories and expressing a $\mathrm{p}$-value as the quantile of the observed differences relative to the random distribution.

Second, we conducted a series of single-species analyzes. We built a site-specific covariate matrix consisting of one record per site, with columns representing year of survey, and site status. We built four survey-specific matrices, each with one record per site and one column for each sample: Julian dates, times of day (evening, morning), count durations, and protocols (ARU, passive point count, point count with playback of mobbing calls). Then, for each species encountered at least 50 times in sites meeting the site selection criteria (see above), we built a matrix with one record per site per year, with one column for each sample, and cells containing presence/absence data. 
We compared three occupancy models for species with small home ranges. To limit the number of competing models,each of them included the same detection covariates : Protocol + Duration + Time + Julian.

1. $\sim$ Protocol + Duration + Time + Julian $\sim$ Year $\{$ null model $\}$

2. $\sim$ Protocol + Duration + Time + Julian $\sim$ Year + Status

3. $\sim$ Protocol + Duration + Time + Julian $\sim$ Year $*$ Status

The first model incorporated only detection covariates, with a hypothesized temporal trend on site occupancy. We designed the second model to evaluate the additive effects of trend and status, i.e. fixed occupancy differences between natural, unrestored and restored sites. The third model evaluated a temporal change in the differences between occupancies of natural, unrestored and restored sites.

We ran the suite of models first with natural, unrestored, and or restored sites to get general patterns, and re-ran the models with unrestored and restored sites only, to test whether site restoration was associated to changes in species occupancy. To estimate species responses to site restoration (vs. unrestored) we used multimodel inference, with occupancy estimates for site status averaged between models, weighted by model AICc weight (Burnham and Anderson, 2002).

\section{Bird with large home ranges}

We followed the same modelling approach as with species with small home ranges, with the following differences. The site-specific covariate matrix consisted of one record per bog, with columns representing year of survey, and log areas of peat-extracted, natural, unrestored, and restored sites. Logs were used because we believe that a fixed increment in area, say 1 ha, has greater importance in small areas than in larger areas. We built four survey-specific matrices, each with one record per site and one column for each sample: Julian dates, times of day (evening, morning), count durations, and protocols (ARU, passive point count, point count with playback of mobbing calls).

We compared seven occupancy models for species with large home ranges. '.' refer to the same covariates as in the previous set of models.

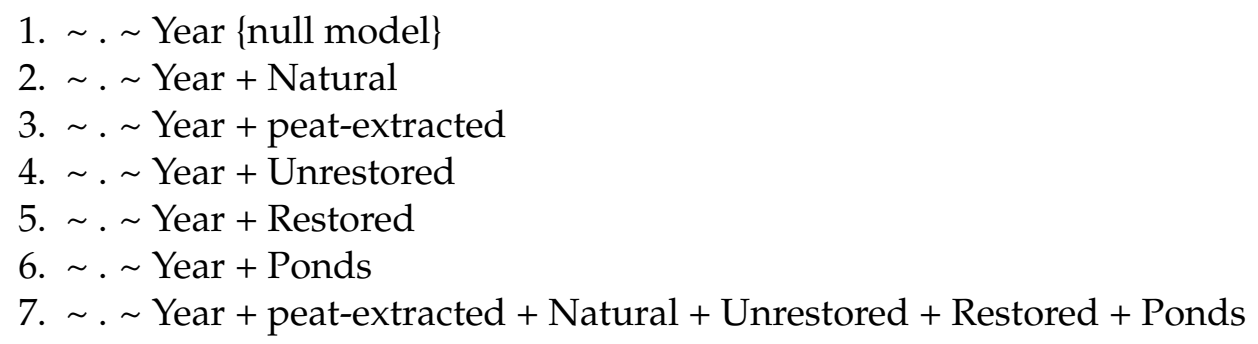

Each model used the same detection covariates as in the models for species with small home ranges. Models were designed to evaluate a general trend in occupancy from 1993 to 2019, irrespective of bog characteristics (null model), and the isolated or additive effects of areas of each bog characteristic.

\section{Bird species assemblages}

We compared bird species assemblages of natural, unrestored and restored sites, based on 41 species observed at least 10 times in sites selected for the single-species analyses. We used a 
multivariate approach based on site $\mathrm{x}$ species matrices: a dendrogram for visualisation, and a Mantel test for hypothesis testing (Legendre et al., 2015, and references therein). In both cases we used binary distance estimates for each pairwise site comparison, i.e. the proportion of species which were present at only one of the two sites. With the Mantel test, we tested whether the site $\mathrm{x}$ site distance matrix for species was correlated to the distance matrix for site status (natural, unrestored, restored). Two analyses were performed, one including the three status types, the other comparing only unrestored and restored sites. A Mantel correlation of zero is obtained when species assemblages are independent of site status. We performed 10000 permutations for each partial Mantel test.

All data preparation and statistical analyses were performed with $\mathrm{R}$ and associated $t i d y v e r s e$ and a iccmodavg packages (R Core Team, 2020; Wickham et al., 2019; Mazerolle, 2020).

\section{Results}

\section{Bog land cover and vegetation strata}

Land cover statistics include only bogs sampled in the current study, and may not be representative of the entire set of peat-extracted bogs in Quebec, New Brunswick or Canada. Within the sampled bogs, the cover area changed greatly between 1993 and 2019. In the sampled bogs, restored sites went from zero to 818 ha, but we observed a net decrease of natural sites and ponds of $15 \%$ and a $81 \%$ net increase of unrestored sites (Table 2 ).

In 2019, restored sites represented $22.6 \%$ of areas where peat extraction has ended. Vegetation cover has changed markedly over the years since extracted peat sites were left unrestored. We restricted the comparison to the first 17 years since no restored site was older than this at the time of the study. Based on 146 natural, 221 unrestored and 52 restored sampling sites, Sphagnum/moss cover area increased steadily, reaching natural levels ca. $10 \mathrm{y}$ after restoration but not in unrestored sites (Fig. 2; paired samples $t$-test, $t=4.5, p=0.0009$ ). Herbaceous strata rapidly reached high percent cover in restored sites, but remained in the natural range in unrestored sites $(t=4.7, p$ $=0.0006)$. Percent cover of other strata was independent of restoration $(p>0.05)$ but Ericaceous shrubs approached natural levels after $17 \mathrm{y}$.

\section{Birds with small home ranges}

We recorded 94 bird species, most of which were uncommon (Appendix 1). The 10 most commonly recorded birds were White-throated Sparrow, Common Yellowthroat, Lincoln's Sparrow, Hermit Thrush, Savannah Sparrow, Palm Warbler, American Crow, American Goldfinch, American Robin, and Alder Flycatcher (by decreasing order), and accounted for $69 \%$ of all individuals recorded. Of those species, only crows have large home ranges. Maximum cumulative numbers of species were very similar among bog types (Fig. 3). However, they were slightly lower in unrestored sites than in natural or restored sites (permutation test, $p<0.001$ ).

The probability of detection of species with small home ranges during a point count averaged 0.54 . However, probabilities of detection varied greatly among species, lowest for American Robin (0.33) and highest for Common Yellowthroat (0.8). Among the 15 species selected for analysis, 6 were significantly associated to one or another of the unrestored, restored, or natural site categories. They were: Alder Flycatcher, American Goldfinch, Palm Warbler, Savannah Sparrow, Song Sparrow, and Yellow-rumped Warbler (Table 3). The habitat associations of 4 of these species appears to have changed with time, as evidenced by their best occupancy model, which included 
Table 2: Net temporal change in the land cover of bogs within $2 \mathrm{~km}$ of sampling sites, 1993-2019. RDL stands for the Rivière-du-Loup peatland complex. Values are in hectares (as of 1993), with changes from 1993 to 2019 in parentheses.

\begin{tabular}{|c|c|c|c|c|c|c|}
\hline Name & Location & Natural & Ponds & Extracted & Unrestored & Restored \\
\hline Bagotville & $48.36 \mathrm{~N}, 70.94 \mathrm{~W}$ & $496.1(0)$ & $0(0)$ & $0(0)$ & $109.6(0)$ & $0.0(0)$ \\
\hline Bois-des-Bel & $47.97 \mathrm{~N}, 69.43 \mathrm{~W}$ & $185.5(0)$ & $0(0.1)$ & $0(0)$ & $11.1(-7.5)$ & $0.0(7.4)$ \\
\hline Cacouna-Station & $47.88 \mathrm{~N}, 69.45 \mathrm{~W}$ & $71.6(0)$ & $0(0)$ & $0(0)$ & $86.8(0)$ & $0.0(0)$ \\
\hline Coteau-du-Tuf & $47.97 \mathrm{~N}, 69.37 \mathrm{~W}$ & $2.5(0)$ & $0(0)$ & $0(4.2)$ & $24.8(-4.2)$ & $0.0(0)$ \\
\hline Grande Plée Bleue & $46.77 \mathrm{~N}, 71.07 \mathrm{~W}$ & $590.2(0)$ & $15(0)$ & $0(0)$ & $0(0)$ & $0.0(0)$ \\
\hline Ile-aux-Coudres & $47.41 \mathrm{~N}, 70.36 \mathrm{~W}$ & $71.5(-20)$ & $0(0)$ & $74.8(-74.8)$ & $23.5(94.8)$ & $0.0(0)$ \\
\hline Inkerman & $47.71 \mathrm{~N}, 64.81 \mathrm{~W}$ & $736(-149.8)$ & $11.7(-5.3)$ & $197.7(136.9)$ & $65.2(6.5)$ & $0.0(11.6)$ \\
\hline Isle-Verte & $48.03 \mathrm{~N}, 69.31 \mathrm{~W}$ & $27.3(0)$ & $0(0)$ & $0(0)$ & $89(0)$ & $0.0(0)$ \\
\hline Isle-Verte SW & $47.98 \mathrm{~N}, 69.33 \mathrm{~W}$ & $0(0)$ & $0(0)$ & $35.5(-35.5)$ & $0(35.5)$ & $0.0(0)$ \\
\hline L'Ascension Ouest & $48.73 \mathrm{~N}, 71.7 \mathrm{~W}$ & $1948.2(-98.6)$ & $11.2(0)$ & $109.6(79.8)$ & $4.7(-0.2)$ & $0.0(19)$ \\
\hline Lac Malobès & $48.25 \mathrm{~N}, 68.88 \mathrm{~W}$ & $0(0)$ & $0(0)$ & $0(0)$ & $9(0)$ & $0.0(0)$ \\
\hline Le Parc & $47.87 \mathrm{~N}, 69.49 \mathrm{~W}$ & $9.4(0)$ & $0(0)$ & $0(0)$ & $36.1(0)$ & $0.0(0)$ \\
\hline Les Escoumins & $48.32 \mathrm{~N}, 69.45 \mathrm{~W}$ & $605.8(-66.3)$ & $7.6(-2.7)$ & $105.8(77.1)$ & $26.1(-21.8)$ & $0.0(13.8)$ \\
\hline ND-du-Portage & $47.74 \mathrm{~N}, 69.61 \mathrm{~W}$ & $119.2(0)$ & $0(0)$ & $101(-101)$ & $28.6(101)$ & $0.0(0)$ \\
\hline Pointe-au-Père & $48.49 \mathrm{~N}, 68.47 \mathrm{~W}$ & $48.5(0)$ & $0(0)$ & $171.6(-171.6)$ & $12.6(148.9)$ & $0.0(22.8)$ \\
\hline Pointe-Lebel & $49.14 \mathrm{~N}, 68.26 \mathrm{~W}$ & $1762.3(-358.2)$ & $198.2(-5.6)$ & $610.4(104.3)$ & $1.7(205.9)$ & $0.0(53.6)$ \\
\hline Pokesudie & $47.81 \mathrm{~N}, 64.77 \mathrm{~W}$ & $113(0)$ & $3.1(0)$ & $81.1(-81.1)$ & $58.3(-31.3)$ & $0.0(112.4)$ \\
\hline RDL Centre & $47.8 \mathrm{~N}, 69.49 \mathrm{~W}$ & $7.4(0)$ & $0(0)$ & $0(12.5)$ & $135.1(-23.8)$ & $0.0(0)$ \\
\hline RDL Chemin-du-Lac & $47.76 \mathrm{~N}, 69.53 \mathrm{~W}$ & $26.5(-12.5)$ & $0(0.9)$ & $208(-197.3)$ & $13.5(151)$ & $0.0(56.2)$ \\
\hline RDL Chemin-du-Lac 2 & $47.78 \mathrm{~N}, 69.52 \mathrm{~W}$ & $0(0)$ & $0(0)$ & $70.4(-13)$ & $0(13)$ & $0.0(0)$ \\
\hline RDL Côte-Sud & $47.84 \mathrm{~N}, 69.47 \mathrm{~W}$ & $145.1(0)$ & $0(0)$ & $106.1(-52.9)$ & $18.6(51.6)$ & $0.0(1.3)$ \\
\hline RDL Président-Ouest & $47.79 \mathrm{~N}, 69.5 \mathrm{~W}$ & $363.6(-131)$ & $0(0)$ & $241.4(12.5)$ & $47.7(96.4)$ & $0.0(22.1)$ \\
\hline RDL St-Laurent & $47.82 \mathrm{~N}, 69.47 \mathrm{~W}$ & $271.3(-70.9)$ & $0(0)$ & $214.3(134.3)$ & $371.9(-82)$ & $0.0(18.6)$ \\
\hline RDL St-Laurent 2 & $47.82 \mathrm{~N}, 69.46 \mathrm{~W}$ & $3.9(0)$ & $0(0)$ & $59.7(31.1)$ & $31.2(-31.2)$ & $0.0(0)$ \\
\hline RDL St-Modeste & $47.85 \mathrm{~N}, 69.45 \mathrm{~W}$ & $0(0)$ & $0(0)$ & $52.3(-5.3)$ & $26.8(5.3)$ & $0.0(0)$ \\
\hline RDL St-Modeste 2 & $47.83 \mathrm{~N}, 69.45 \mathrm{~W}$ & $0.9(-0.9)$ & $0(0)$ & $45(-44.1)$ & $0(45)$ & $0.0(0)$ \\
\hline RDL St-Modeste 3 & $47.84 \mathrm{~N}, 69.48 \mathrm{~W}$ & $0(0)$ & $0(0)$ & $15.3(-15.3)$ & $0(15.3)$ & $0.0(0)$ \\
\hline RDL Verbois & $47.84 \mathrm{~N}, 69.45 \mathrm{~W}$ & $32.7(-32.7)$ & $0(0)$ & $170.4(-35.5)$ & $8.2(39)$ & $0.0(29.3)$ \\
\hline Rivière-Ouelle & $47.47 \mathrm{~N}, 69.93 \mathrm{~W}$ & $984.4(-242.7)$ & $0(0)$ & $480.5(238.4)$ & $30.2(-3.8)$ & $0.0(4.4)$ \\
\hline St-Alexandre & $47.66 \mathrm{~N}, 69.67 \mathrm{~W}$ & $49(0)$ & $0(0)$ & $266.3(-266.3)$ & $68.8(266.3)$ & $0.0(0)$ \\
\hline St-Arsène & $47.94 \mathrm{~N}, 69.43 \mathrm{~W}$ & $126.8(0)$ & $0(0)$ & $153(-1.3)$ & $29.6(1.3)$ & $0.0(0)$ \\
\hline St-Bonaventure & $45.95 \mathrm{~N}, 72.7 \mathrm{~W}$ & $173.8(-78.6)$ & $0(0)$ & $132.4(36.9)$ & $74(41.7)$ & $0.0(0)$ \\
\hline St-Charles & $46.79 \mathrm{~N}, 70.96 \mathrm{~W}$ & $938.6(-126.1)$ & $20.1(-3.4)$ & $140.8(98.9)$ & $48.6(25.8)$ & $0.0(4.7)$ \\
\hline St-Fabien & $48.31 \mathrm{~N}, 68.87 \mathrm{~W}$ & $35.3(0)$ & $0(0)$ & $67.6(-58.2)$ & $4.8(47.4)$ & $0.0(10.8)$ \\
\hline St-Henri & $46.71 \mathrm{~N}, 71.06 \mathrm{~W}$ & $35.9(-7.3)$ & $0.2(0)$ & $123.6(-74.7)$ & $25(7.6)$ & $0.0(74.3)$ \\
\hline St-Ludger-de-Milot SW & $48.87 \mathrm{~N}, 71.82 \mathrm{~W}$ & $778.9(-257.7)$ & $18.8(0)$ & $31.3(230.8)$ & $0(16.1)$ & $0.0(10.8)$ \\
\hline St-Raphael & $47.79 \mathrm{~N}, 64.6 \mathrm{~W}$ & $87.9(0)$ & $0(0)$ & $83(0)$ & $11.8(0)$ & $0.0(0)$ \\
\hline Ste-Marguerite Marie & $48.83 \mathrm{~N}, 72.18 \mathrm{~W}$ & $3562.6(-558)$ & $20.7(0)$ & $276.3(163.8)$ & $14.1(48.9)$ & $0.0(345.3)$ \\
\hline Total & & $14411.7(-2211.3)$ & $306.6(-16)$ & $4425.2(133.6)$ & 1547 (1258.5) & $0.0(818.4)$ \\
\hline
\end{tabular}




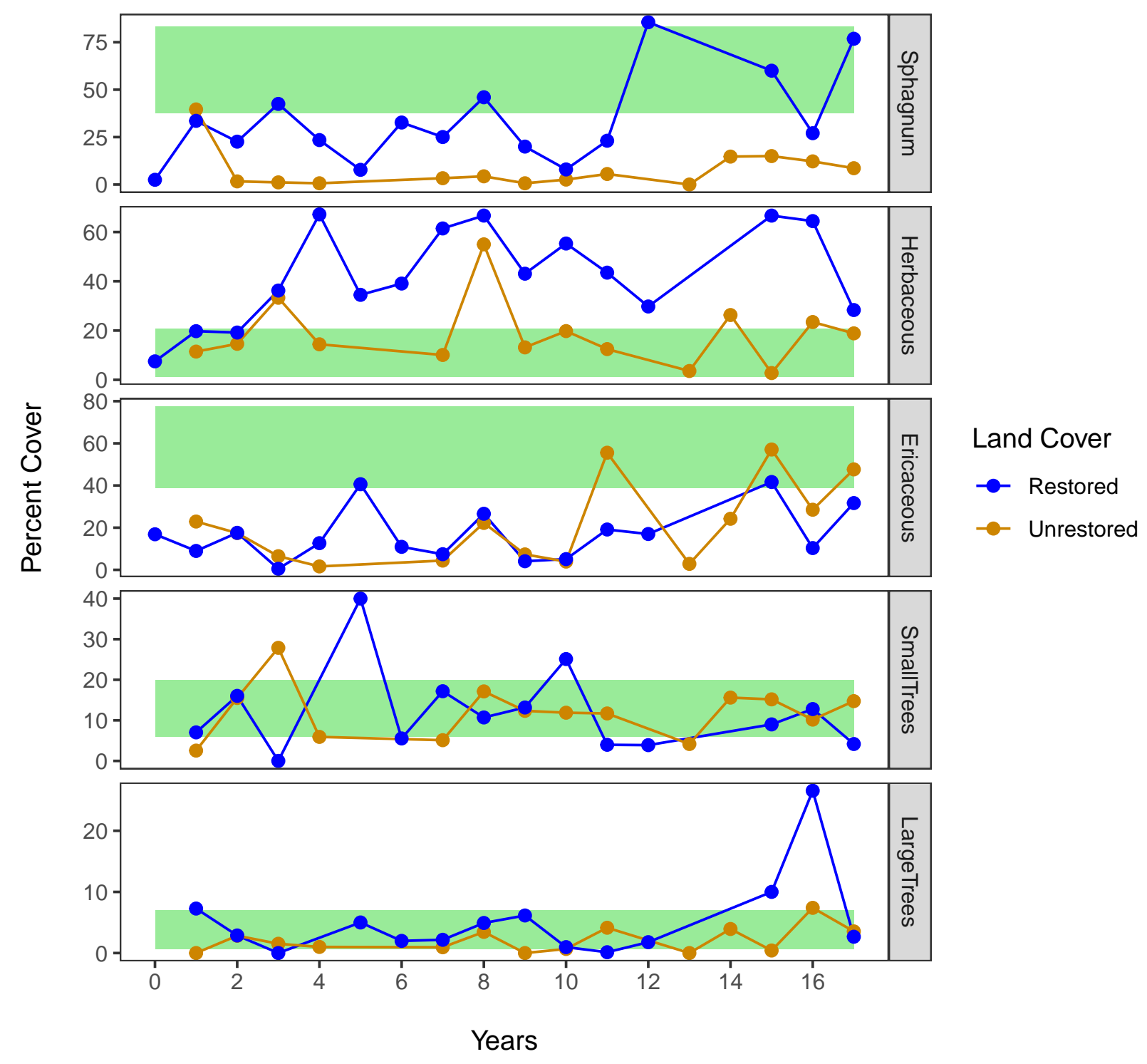

Figure 2: Chronosequence of plant cover across sampled sites. We restricted the comparison to the first 17 years since no restored site was older than this at the time of the study. Green bands represent variability in natural sites (lower and upper quartiles). Peat in sites less than $40 \mathrm{y}$ old was mostly extracted with the vacuum method; older extraction was generally manual (block cut). Only plots with $>1$ ha unrestored or restored were retained for this analysis. 


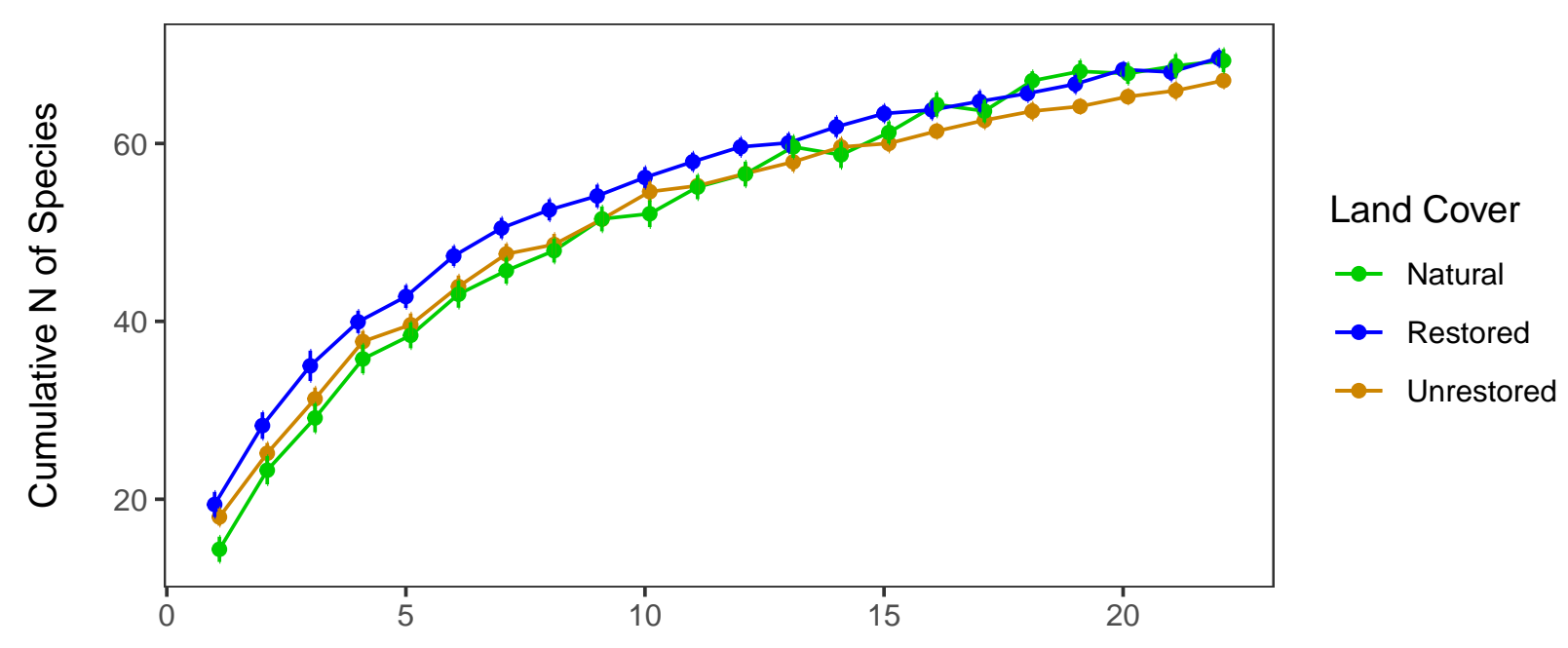

Cumulative $\mathrm{N}$ of Sites

Figure 3: Bird species accumulation curves in natural, unrestored and restored sites. Vertical bars represent bootstrapped standard errors of estimates.

a 'year $\times$ bog status' interaction. Occupancy of restored sites by Palm and Yellow-rumped Warblers increased over the years, reaching levels similar to those in natural sites (Fig. 4). Occupancy of restored sites by Song and Savannah sparrows also increased, but diverged from their occupancy of natural sites over the course of the study (Fig. 4). We must emphasize that the weight of evidence for a changing association to restored, unrestored or natural sites was overwhelming only in the case of Savannah Sparrow. In the other species shown in Table 3, whether differences in occupancy are constant or changing will only be ascertained by further research.

When occupancy of unrestored is compared to restored site occupancy, only the Savannah Sparrow had different occupancies between those sites, as evidenced by the occupancy estimate (logit scale) for bog status effect that did not overlap zero $(\hat{\beta}=2.39[1.17,3.61])$.

Birds with large home ranges

We recorded the following species with large home ranges, or audible from a large distance: American Bittern, American Black Duck, American Crow, American Kestrel, Bank Swallow, Barn Swallow, Belted Kingfisher, Blue Jay, Broad-winged Hawk, Brown-headed Cowbird, Brown Thrasher, Cedar Waxwing, Common Grackle, Common Raven, Eastern Meadowlark, Merlin, Mourning Dove, Northern Harrier, Red-tailed Hawk, Sandhill Crane, Sharp-shinned Hawk, Upland Sandpiper, Tree Swallow, Turkey Vulture, and migrant shorebirds. Migrant shorebirds were composed of 8 species: Greater Yellowlegs, Least Sandpiper, Lesser Yellowlegs, Pectoral Sandpiper, Sanderling, Semipalmated Plover, Semipalmated Sandpiper, and Solitary Sandpiper. Probabilities of detection among species with large home ranges were lowest for migrant shorebirds (0.03) and highest for American Crow (0.45). None of the species responded significantly to the log-transformed areas of ponds, natural, peat-extracted, unrestored and restored sites, after adjusting the type I error risk for multiple testing. 


\section{Alder Flycatcher}

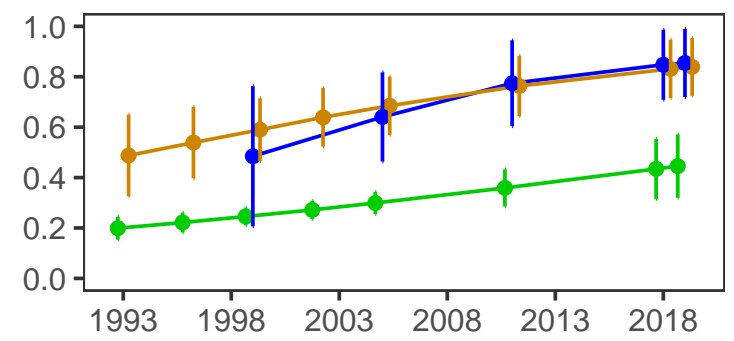

Palm Warbler

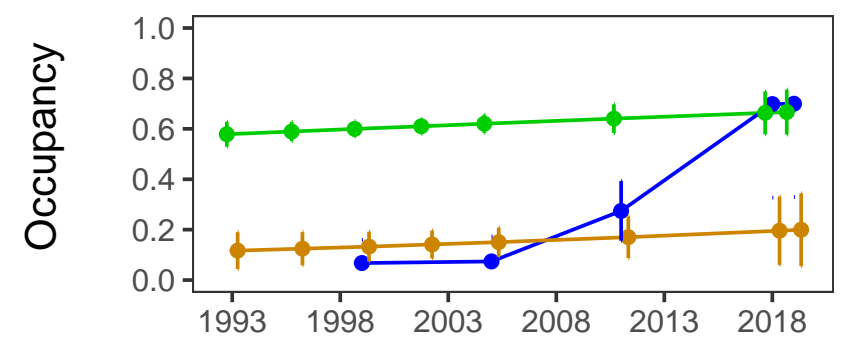

Song Sparrow

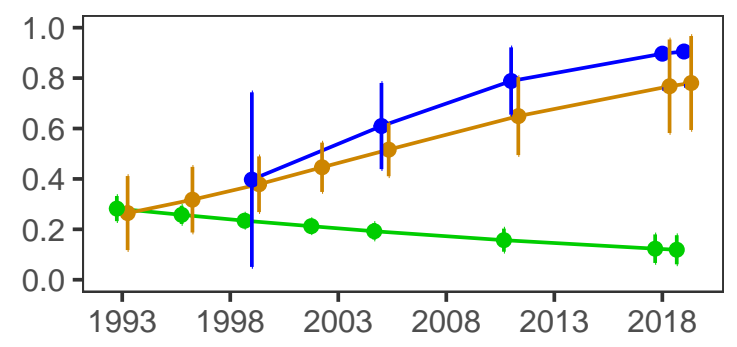

American Goldfinch

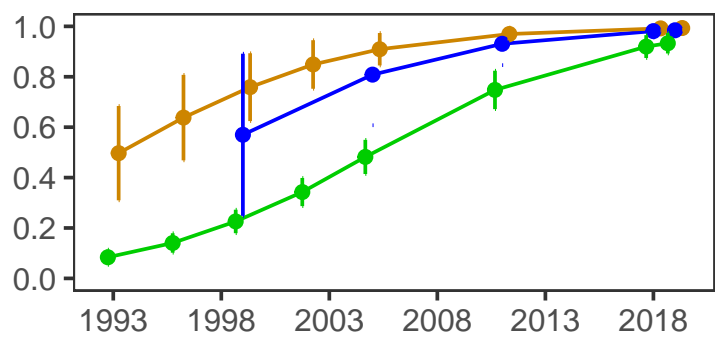

\section{Savannah Sparrow}

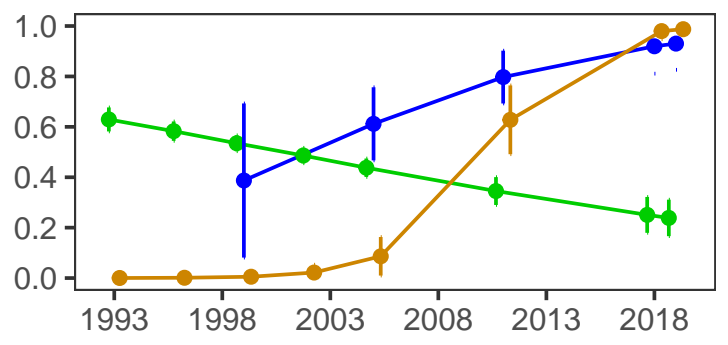

Yellow-rumped Warbler

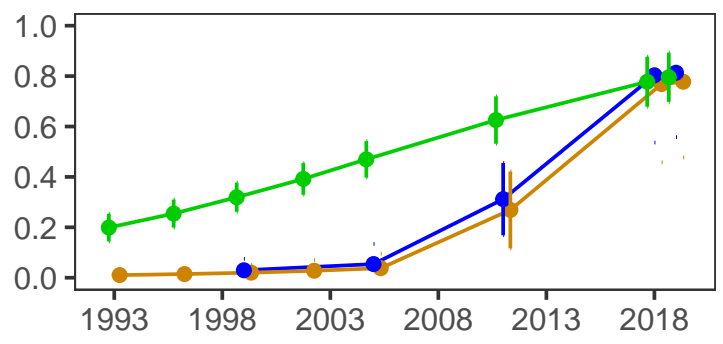

Year

Figure 4: Changing associations to natural, unrestored and restored sites, as determined by occupancy models. Vertical bars represent standard errors of occupancy estimates. 
Table 3: Performance of occupancy models for bird species with small home ranges encountered at least 50 times in the course of the study. Only species for which the null model (year effect only) had a weight less than $5 \%$ (corrected for multiple testing) are shown. K represents the numbers of parameters of each model.

\begin{tabular}{|c|c|c|c|c|c|}
\hline Species & Model & $\mathrm{K}$ & $\mathrm{AICc}$ & Delta & Weight \\
\hline \multirow{3}{*}{ Alder Flycatcher } & Year + Status & 10 & 705.01 & 0.00 & 0.71 \\
\hline & Year $\times$ Status & 12 & 706.85 & 1.84 & 0.28 \\
\hline & Year & 8 & 717.70 & 12.69 & 0.00 \\
\hline \multirow{3}{*}{ American Goldfinch } & Year + Status & 10 & 702.15 & 0.00 & 0.61 \\
\hline & Year x Status & 12 & 703.02 & 0.87 & 0.39 \\
\hline & Year & 8 & 716.72 & 14.57 & 0.00 \\
\hline \multirow{3}{*}{ Palm Warbler } & Year $x$ Status & 12 & 1005.28 & 0.00 & 0.61 \\
\hline & Year + Status & 10 & 1006.17 & 0.89 & 0.39 \\
\hline & Year & 8 & 1045.60 & 40.32 & 0.00 \\
\hline \multirow{3}{*}{ Savannah Sparrow } & Year x Status & 12 & 979.14 & 0.00 & 1.00 \\
\hline & Year + Status & 10 & 1003.36 & 24.21 & 0.00 \\
\hline & Year & 8 & 1018.05 & 38.91 & 0.00 \\
\hline \multirow{3}{*}{ Song Sparrow } & Year $x$ Status & 12 & 707.74 & 0.00 & 0.86 \\
\hline & Year + Status & 10 & 711.40 & 3.66 & 0.14 \\
\hline & Year & 8 & 731.63 & 23.89 & 0.00 \\
\hline \multirow{3}{*}{ Yellow-rumped Warbler } & Year x Status & 12 & 619.15 & 0.00 & 0.65 \\
\hline & Year + Status & 10 & 620.37 & 1.21 & 0.35 \\
\hline & Year & 8 & 632.04 & 12.89 & 0.00 \\
\hline
\end{tabular}




\section{Bird species assemblages}

Species assemblages differed significantly among peat extracted, unrestored and restored sites (Mantel test, $r=0.086, p<0.001$ ). After excluding natural sites, species assemblages remained significantly different between restored and unrestored sites (Mantel test, $r=0.086, p<0.0006$ ). Species assemblages of unrestored and restored sites were very dissimilar to those of natural sites soon after extraction, but became progressively more similar with increasing years post extraction (Fig. 5; $\hat{\beta}=-0.008 \pm 0.002, p<0.003$ ).

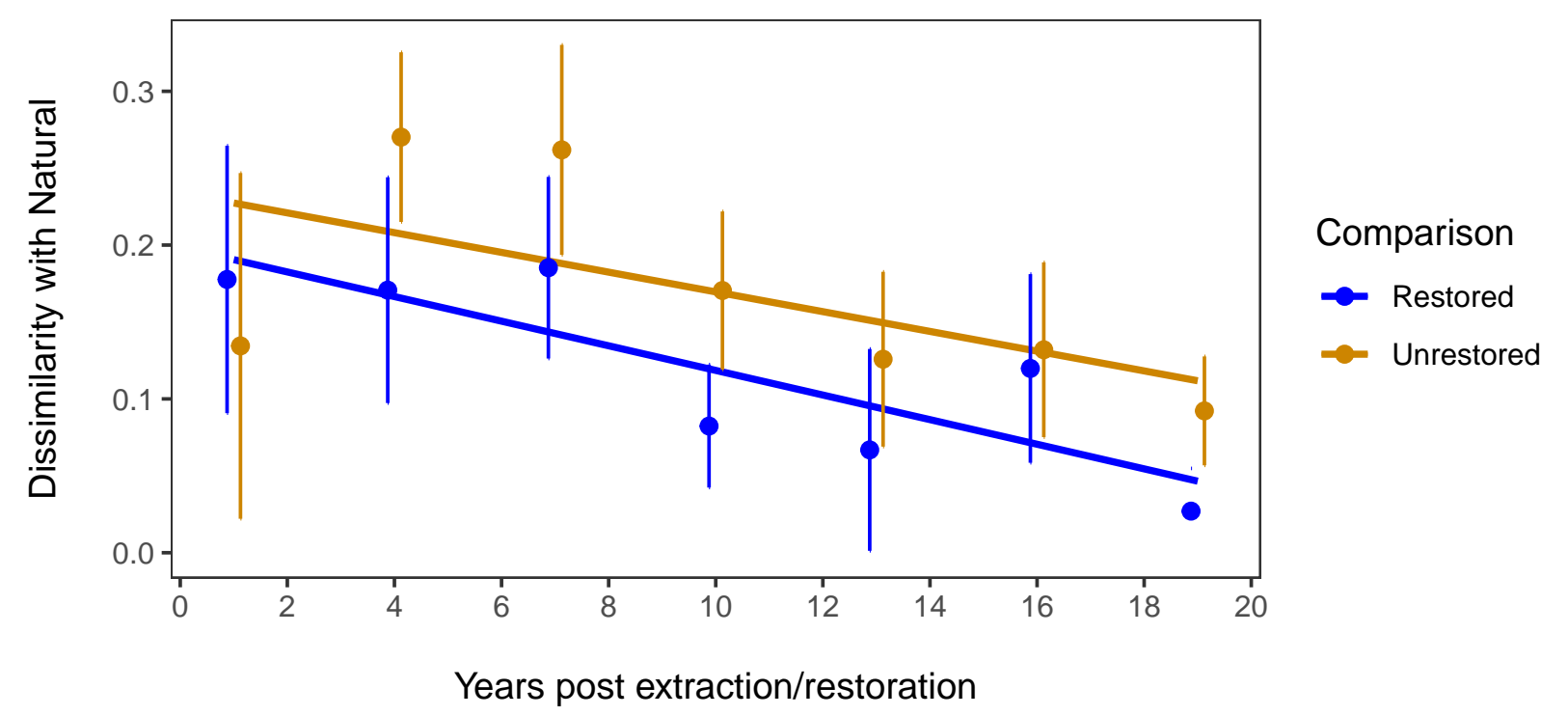

Figure 5: Convergence of bird species assemblages of unrestored and restored sites towards those of natural sites in Eastern canadian bogs, 1993 - 2019.

\section{Discussion}

Bogs subject to peat extraction in Eastern Canada harbour a large number of bird species, but most of them do not occur in those sites regularly, the overall picture resembling a power law (or 'Pareto') distribution, as is the case in many phenomena (Newman, 2005) including species abundances (Ulrich et al., 2010). Species diversity was remarkably similar among natural, unrestored, and restored sites, even though unrestored sites yielded slightly fewer species. As in other studies with the present ecosystem (González and Rochefort, 2014; Purre et al., 2020), we show that low vegetation strata can recover in a matter of a few years after peat extraction has ceased, and that this recovery is facilitated by restoration in the case of moss and herbaceous (mostly sedges) strata (Rochefort et al., 2013). Moreover, we added support to the finding by Desrochers et al. (1998) that tree cover overshot in old unrestored sites that of nearby undisturbed sites, a phenomenon linked to the regional establishment of grey birch (Betula populifolia) in disturbed bogs (Lavoie and Saint-Louis, 1999). In this context, it is not surprising that site occupancy by certain bird species has changed, since birds tend to respond strongly to vegetation structure, at least at coarse spatial scales (e.g. (Rotenberry, 1985)). But the convergence of bird species assemblages of unrestored and restored sites towards those of natural sites is a less trivial, and encouraging, outcome of this study. If species dissimilarity indices are to be trusted, bog restoration efforts may be on the cusp 
of yielding bird species assemblages statistically indistinguishable from those of natural sites.

In his classic monograph on boreal birds of Canada, Erskine (1977) provided an in-depth picture of bird assemblages in Canadian boreal bogs, sometimes termed 'muskeg'. In the 1990s, our research group presented a first outlook on the impact of peat extraction on eastern Canadian birds, with a focus on recolonization (Desrochers et al., 1998). In the natural bogs, we found approximately the same bird species as the ones Erskine found in natural bogs. One notable exception was the Swamp Sparrow, that Erskine depicted as typical of bogs, despite it being rare in the bogs of the present study, and probably more associated to fens. Our 1998 study provided little ground for hope in rebuilding bird assemblages similar to undisturbed bogs. At the time of that study, unrestored vacuum-extracted sites exhibited Sphagnum and ericaceous cover wellbelow levels observed in nearby natural sites, and strikingly different bird species (Desrochers et al., 1998).

Our 1998 study was conducted at a time when bog restoration was still in its infancy, and the ca. 25 years that have elapsed since allow us to provide a more robust assessment of bog recolonization by birds, by documenting long-term changes in bird responses to bog post extraction and restoration. Furthermore, our statistical analyses of single species now benefit from key advances offered by hierarchical modeling that accounts for imperfect detection (Burnham and Anderson, 2002; MacKenzie et al., 2002), thereby providing true occupancy estimates as opposed to occurrence indices such as those used in our earlier work. Only a minority of the species examined exhibited strong differences in occupancy of unrestored, restored and natural sites. Among them, the Savannah Sparrow and the Palm Warbler merit special attention. Savannah Sparrows are found in a variety of open habitats (meadows, crop fields, sand dunes, etc.) and is therefore not a flagship bog species. But the creation of barren sites in bogs, restored or not, seem to have been beneficial for the species, to the point of leading to a greater occupancy of those sites than natural sites which we assumed were optimal for the species, 25 years ago. By contrast, the Palm Warbler, the North American bird most closely associated to bogs in temperate areas (Calmé et al., 2002; Wilson, 2020), seems to have responded well to bog restoration in recent years, while maintaining its occupancy of natural sites.

How does our work compare to other studies of recolonization in restored ecosystems? In the last 20 years, the restoration ecology literature has exploded, but only a small portion of it specifically deals with faunal recolonization (Cross et al., 2019). In most cases, substantial differences have been maintained or even increased between bird assemblages of restored and reference sites. for example, in rehabilitated bauxite mines of northern Australia, Brady and Noske (2010) showed, as in the current study, that species diversity was similar in restored and reference sites, but lasting differences were found in bird species assemblages. In Wisconsin, USA, Hapner et al. (2011) found that restored wetlands were progressively more occupied by oldfield species, and less by wetland-dependent species, likely because of a reduction on the amount of open water (Hapner et al., 2011). Wilson and Bayne (2019) document yet another outcome in Alberta, Canada, where songbird species of reclaimed oil and gas wellsites became more similar to those of nearby mature forest, within 49 years post extraction. The convergence of restored and natural bird species assemblages in our study, and the return of a flagship species, thus falls within the range of documented restoration outcomes, especially if we broaden the definition of ecological restoration to include extensive forestry, where wildlife typically recolonizes clearcut sites after decades of forest succession, in temperate as well as tropical forests (Acevedo-Charry and Aide, 2019, and references therein).

The restoration of raised bogs has been underway not only in North America, but also in Europe, most notably in Baltic countries (Karofeld et al., 2017). From the ornithological point of view, advances have been made to restore bogs for a few selected species such as the Golden Plover (Plu- 
vialis apricaria), whose regional decline has been attributed in part to the loss of nesting habitat (Minayeva et al., 2017). Finland presents a particular case, with over $300 \mathrm{~km}^{2}$ of forested peatlands restored by blocking drainage ditches following agriculture and forestry (Alsila et al., 2021). To our knowledge, the only quantitative assessment of the effectiveness of peatland restoration for birds in northern Europe comes from Alsila et al. (2021), who found no response to restoration by peatland specialist birds, based on annual surveys just before restoration and up to 8 y post restoration. One key difference in bird life between European and North American bogs, at least in regions where peat extraction occurs, is the prevalence of songbirds and the paucity of ducks and shorebirds in the latter (Desrochers and van Duinen, 2006). It is therefore likely that bog restoration success in northern Europe will hinge on the ability to rebuild ponds in sites where peat has been extracted.

Moving goal posts

Recolonization by flagship bird species may mark the success of ecological restoration from an ornithological perspective. But more generally, what marks the success of ecological restoration? The question has been debated for some time (Ruiz-Jaen and Mitchell Aide, 2005) and answers will undoubtedly vary because of the diversity of stated objectives. Even in the relatively simple case of vegetation recovery, proponents of ecological restoration are daunted by the challenge of defining goals in a constantly changing environment, with moving goal posts. What amount of ecological variation in time and space can be considered desirable? To compound the problem, the "goal posts" of site recolonization by mobile animals such as birds can be moving independently of abiotic factors, vegetation structure, policy targets, etc., because of regional and sometimes faraway factors, in the case of long-distance migrants. This problem is well illustrated with Savannah Sparrows, whose "reference" level of abundance has been declining in the last 25 years, for reasons probably unrelated to the fortunes of bogs under production. Conversely, the "reference" level of abundance of Sandhill Cranes has moved to vanishingly small to very high in the province of Quebec since the onset of the present study, again with no apparent link to peat extraction. So one may ask, how many Savannah Sparrows or Sandhill Cranes would be considered ideal in restored bogs?

Besides the "moving goal posts" problem, ecological restoration may suffer from an overly restrictive focus on reference ecosystems, without an openness to unexpected opportunity. In the Czech Republic, Šálek (2012) discovered that restoration efforts actually reduced the value of post mining sites for birds, because they focused on the establishment of trees, to the detriment of barren grounds which were more beneficial for regionally-endangered birds. In a similar vein, vacuum-harvesting of peat, with no subsequent restoration, has inadvertently created novel habitats for species of concern in the region concerned by the present study, such as Savannah Sparrow (documented above), Vesper Sparrow, Killdeer and Common Nighthawk. Populations of those species have declined precipitously in Canada since 1970 (by $64 \%, 61 \%$, and $49 \%$ respectively; (NABCI, 2019)). Those declining species are associated to barren sites, not to dense ericaceous shrubs. We observed the latter three species frequently in the extracted bogs of this study, but they were seldom, if at all, observed in undisturbed bogs (Calmé and Desrochers, 2000, 1999). Thus for certain species, the lack of intervention may lead to more desirable outcomes than active restoration.

If land cover management and restoration success result in the conservation of sizable areas of undisturbed and restored peatlands, those habitats may be able to persist longer than surrounding upland habitat, because of their hydrological resilience (Waddington et al. 2015). Restored and natural bogs will continue to provide opportunity to measure restoration, recolonization, and 
perhaps unexpected opportunity.

\section{Acknowledgments}

This research was funded by Natural Science and Engineering Research Council of Canada's, the Canadian Sphagnum Peat Moss Association and its numerous corporate members, as well as a Wildlife Habitat Canada grant to André Desrochers. Thanks to Alexandre Rivard, Bertrand LeGrand, Bruno Drolet, Christian Marcotte, Christine Renaud, Fanny Senez-Gagnon, Jean-François Ouellet, Jean-François Rousseau, Jean-Pierre Savard, Nathalie Pelletier, and Stéphanie Haddad for their participation in bird point counts. Stéphanie Boudreau provided helpful criticism on an earlier version of this article. 


\section{Appendix}

Table 4: List of species, by decreasing number of records.

\begin{tabular}{|c|c|c|c|c|c|}
\hline English name & Scientific name & Natural & Unrestored & Restored & Total \\
\hline Common Yellowthroat & Geothlypis trichas & 1895 & 228 & 161 & 2284 \\
\hline White-throated Sparrow & Zonotrichia albicollis & 1599 & 299 & 188 & 2086 \\
\hline Lincoln's Sparrow & Melospiza lincolnii & 1260 & 103 & 95 & 1458 \\
\hline Savannah Sparrow & Passerculus sandwichensis & 879 & 48 & 131 & 1058 \\
\hline Palm Warbler & Setophaga palmarum & 966 & 20 & 38 & 1024 \\
\hline Hermit Thrush & Catharus guttatus & 710 & 121 & 129 & 960 \\
\hline American Crow & Corvus brachyrhynchos & 423 & 87 & 89 & 599 \\
\hline Alder Flycatcher & Empidonax alnorum & 261 & 101 & 115 & 477 \\
\hline American Goldfinch & Spinus tristis & 225 & 130 & 94 & 449 \\
\hline Song Sparrow & Melospiza melodia & 244 & 96 & 90 & 430 \\
\hline American Robin & Turdus migratorius & 246 & 88 & 82 & 416 \\
\hline Magnolia Warbler & Setophaga magnolia & 260 & 45 & 35 & 340 \\
\hline Ruby-crowned Kinglet & Regulus calendula & 245 & 26 & 29 & 300 \\
\hline Red-winged Blackbird & Agelaius phoeniceus & 179 & 44 & 67 & 290 \\
\hline Yellow-rumped Warbler & Setophaga coronata & 231 & 16 & 24 & 271 \\
\hline Red-eyed Vireo & Vireo olivaceus & 96 & 47 & 50 & 193 \\
\hline Purple Finch & Haemorhous purpureus & 128 & 11 & 12 & 151 \\
\hline Cedar Waxwing & Bombycilla cedrorum & 101 & 20 & 10 & 131 \\
\hline Swainson's Thrush & Catharus ustulatus & 82 & 19 & 20 & 121 \\
\hline Veery & Catharus fuscescens & 49 & 39 & 27 & 115 \\
\hline Common Grackle & Quiscalus quiscula & 86 & 10 & 16 & 112 \\
\hline American Redstart & Setophaga ruticilla & 56 & 25 & 28 & 109 \\
\hline Black-capped Chickadee & Poecile atricapillus & 63 & 19 & 20 & 102 \\
\hline Swamp Sparrow & Melospiza georgiana & 8 & 31 & 56 & 95 \\
\hline Blue Jay & Cyanocitta cristata & 65 & 4 & 14 & 83 \\
\hline Wilson's Snipe & Gallinago delicata & 31 & 18 & 33 & 82 \\
\hline Nashville Warbler & Leiothlypis ruficapilla & 45 & 12 & 23 & 80 \\
\hline Common Raven & Corvus corax & 44 & 10 & 20 & 74 \\
\hline Killdeer & Charadrius vociferus & 31 & 27 & 11 & 69 \\
\hline American Black Duck & Anas rubripes & 54 & 6 & 5 & 65 \\
\hline Northern Harrier & Circus hudsonius & 47 & 10 & 7 & 64 \\
\hline Tree Swallow & Tachycineta bicolor & 52 & 4 & 7 & 63 \\
\hline Eastern Kingbird & Tyrannus tyrannus & 54 & 3 & 5 & 62 \\
\hline Vesper Sparrow & Pooecetes gramineus & 11 & 22 & 26 & 59 \\
\hline Philadelphia Vireo & Vireo philadelphicus & 32 & 12 & 13 & 57 \\
\hline Northern Flicker & Colaptes auratus & 19 & 11 & 21 & 51 \\
\hline Winter Wren & Troglodytes hiemalis & 37 & 7 & 6 & 50 \\
\hline Chestnut-sided Warbler & Setophaga pensylvanica & 22 & 13 & 9 & 44 \\
\hline Brown-headed Cowbird & Molothrus ater & 30 & 7 & 6 & 43 \\
\hline Dark-eyed Junco & Junco hyemalis & 30 & 5 & 5 & 40 \\
\hline Ovenbird & Seiurus aurocapilla & 28 & 10 & 2 & 40 \\
\hline Golden-crowned Kinglet & Regulus satrapa & 36 & 2 & 1 & 39 \\
\hline Mourning Dove & Zenaida macroura & 31 & 6 & 0 & 37 \\
\hline Pine Siskin & Spinus pinus & 27 & 3 & 7 & 37 \\
\hline Boreal Chickadee & Poecile hudsonicus & 31 & 1 & 2 & 34 \\
\hline Upland Sandpiper & Bartramia longicauda & 34 & 0 & 0 & 34 \\
\hline Mallard & Anas platyrhynchos & 24 & 2 & 7 & 33 \\
\hline
\end{tabular}


Table 4: List of species, by decreasing number of records. (continued)

\begin{tabular}{|c|c|c|c|c|c|}
\hline English name & Scientific name & Natural & Unrestored & Restored & Total \\
\hline Red-breasted Nuthatch & Sitta canadensis & 20 & 4 & 6 & 30 \\
\hline Yellow-bellied Flycatcher & Empidonax flaviventris & 23 & 3 & 3 & 29 \\
\hline Black-and-white Warbler & Mniotilta varia & 22 & 3 & 0 & 25 \\
\hline Canada Goose & Branta canadensis & 17 & 1 & 7 & 25 \\
\hline Common Loon & Gavia immer & 16 & 6 & 3 & 25 \\
\hline White-winged Crossbill & Loxia leucoptera & 22 & 2 & 1 & 25 \\
\hline American Woodcock & Scolopax minor & 12 & 9 & 2 & 23 \\
\hline Least Flycatcher & Empidonax minimus & 3 & 10 & 8 & 21 \\
\hline Tennessee Warbler & Leiothlypis peregrina & 7 & 1 & 13 & 21 \\
\hline Olive-sided Flycatcher & Contopus cooperi & 18 & 1 & 1 & 20 \\
\hline Blue-headed Vireo & Vireo solitarius & 12 & 6 & 1 & 19 \\
\hline Yellow Warbler & Setophaga petechia & 4 & 10 & 5 & 19 \\
\hline Bobolink & Dolichonyx oryzivorus & 9 & 3 & 6 & 18 \\
\hline Black-throated Green Warbler & Setophaga virens & 11 & 4 & 1 & 16 \\
\hline Barn Swallow & Hirundo rustica & 8 & 2 & 5 & 15 \\
\hline Evening Grosbeak & Coccothraustes vespertinus & 10 & 5 & 0 & 15 \\
\hline Gray Catbird & Dumetella carolinensis & 12 & 0 & 3 & 15 \\
\hline American Bittern & Botaurus lentiginosus & 4 & 0 & 10 & 14 \\
\hline Bank Swallow & Riparia riparia & 7 & 0 & 5 & 12 \\
\hline Short-eared Owl & Asio flammeus & 12 & 0 & 0 & 12 \\
\hline No birds & Non avium & 5 & 0 & 5 & 10 \\
\hline Sandhill Crane & Antigone canadensis & 6 & 2 & 2 & 10 \\
\hline Brown Thrasher & Toxostoma rufum & 0 & 0 & 9 & 9 \\
\hline Common Nighthawk & Chordeiles minor & 5 & 1 & 3 & 9 \\
\hline Great Blue Heron & Ardea herodias & 6 & 2 & 1 & 9 \\
\hline Mourning Warbler & Geothlypis philadelphia & 5 & 3 & 1 & 9 \\
\hline Rusty Blackbird & Euphagus carolinus & 8 & 1 & 0 & 9 \\
\hline Green-winged Teal & Anas crecca & 6 & 0 & 2 & 8 \\
\hline Herring Gull & Larus argentatus & 5 & 0 & 3 & 8 \\
\hline Northern Waterthrush & Parkesia noveboracensis & 6 & 1 & 0 & 7 \\
\hline Ruby-throated Hummingbird & Archilochus colubris & 5 & 2 & 0 & 7 \\
\hline Wilson's Warbler & Cardellina pusilla & 2 & 1 & 4 & 7 \\
\hline Blackpoll Warbler & Setophaga striata & 5 & 1 & 0 & 6 \\
\hline Chipping Sparrow & Spizella passerina & 2 & 2 & 2 & 6 \\
\hline Ring-billed Gull & Larus delawarensis & 4 & 1 & 0 & 5 \\
\hline Yellow-bellied Sapsucker & Sphyrapicus varius & 5 & 0 & 0 & 5 \\
\hline American Pipit & Anthus rubescens & 3 & 1 & 0 & 4 \\
\hline Bay-breasted Warbler & Setophaga castanea & 4 & 0 & 0 & 4 \\
\hline Black-billed Cuckoo & Coccyzus erythropthalmus & 2 & 0 & 2 & 4 \\
\hline Cape May Warbler & Setophaga tigrina & 1 & 2 & 1 & 4 \\
\hline Cliff Swallow & Petrochelidon pyrrhonota & 4 & 0 & 0 & 4 \\
\hline Fox Sparrow & Passerella iliaca & 4 & 0 & 0 & 4 \\
\hline Osprey & Pandion haliaetus & 3 & 0 & 1 & 4 \\
\hline Pied-billed Grebe & Podilymbus podiceps & 0 & 0 & 4 & 4 \\
\hline Pileated Woodpecker & Dryocopus pileatus & 2 & 0 & 2 & 4 \\
\hline American Wigeon & Mareca americana & 0 & 0 & 3 & 3 \\
\hline Canada Warbler & Cardellina canadensis & 2 & 1 & 0 & 3 \\
\hline Double-crested Cormorant & Phalacrocorax auritus & 1 & 2 & 0 & 3 \\
\hline Great Crested Flycatcher & Myiarchus crinitus & 3 & 0 & 0 & 3 \\
\hline Least Sandpiper & Calidris minutilla & 2 & 0 & 1 & 3 \\
\hline
\end{tabular}


bioRxiv preprint doi: https://doi.org/10.1101/2021.11.26.470119; this version posted November 27, 2021. The copyright holder for this preprint (which was not certified by peer review) is the author/funder, who has granted bioRxiv a license to display the preprint in perpetuity. It is made available under aCC-BY-NC-ND 4.0 International license.

Table 4: List of species, by decreasing number of records. (continued)

\begin{tabular}{|c|c|c|c|c|c|}
\hline English name & Scientific name & Natural & Unrestored & Restored & Total \\
\hline Northern Parula & Setophaga americana & 1 & 2 & 0 & 3 \\
\hline Scarlet Tanager & Piranga olivacea & 2 & 1 & 0 & 3 \\
\hline Sharp-shinned Hawk & Accipiter striatus & 2 & 0 & 1 & 3 \\
\hline Spotted Sandpiper & Actitis macularius & 2 & 0 & 1 & 3 \\
\hline American Kestrel & Falco sparverius & 2 & 0 & 0 & 2 \\
\hline Bald Eagle & Haliaeetus leucocephalus & 1 & 1 & 0 & 2 \\
\hline Belted Kingfisher & Megaceryle alcyon & 2 & 0 & 0 & 2 \\
\hline Canada Jay & Perisoreus canadensis & 2 & 0 & 0 & 2 \\
\hline Northern Hawk Owl & Surnia ulula & 2 & 0 & 0 & 2 \\
\hline Red-tailed Hawk & Buteo jamaicensis & 2 & 0 & 0 & 2 \\
\hline Rose-breasted Grosbeak & Pheucticus ludovicianus & 2 & 0 & 0 & 2 \\
\hline Ruffed Grouse & Bonasa umbellus & 2 & 0 & 0 & 2 \\
\hline Solitary Sandpiper & Tringa solitaria & 0 & 1 & 1 & 2 \\
\hline Black-throated Blue Warbler & Setophaga caerulescens & 1 & 0 & 0 & 1 \\
\hline Blackburnian Warbler & Setophaga fusca & 1 & 0 & 0 & 1 \\
\hline Clay-colored Sparrow & Spizella pallida & 1 & 0 & 0 & 1 \\
\hline Common Tern & Sterna hirundo & 0 & 0 & 1 & 1 \\
\hline Downy Woodpecker & Dryobates pubescens & 0 & 0 & 1 & 1 \\
\hline Eastern Bluebird & Sialia sialis & 1 & 0 & 0 & 1 \\
\hline Eastern Meadowlark & Sturnella magna & 0 & 1 & 0 & 1 \\
\hline Eastern Wood-Pewee & Contopus virens & 1 & 0 & 0 & 1 \\
\hline Great Black-backed Gull & Larus marinus & 0 & 1 & 0 & 1 \\
\hline Great Gray Owl & Strix nebulosa & 1 & 0 & 0 & 1 \\
\hline Greater Yellowlegs & Tringa melanoleuca & 0 & 0 & 1 & 1 \\
\hline Hairy Woodpecker & Dryobates villosus & 0 & 0 & 1 & 1 \\
\hline Horned Lark & Eremophila alpestris & 1 & 0 & 0 & 1 \\
\hline Lesser Yellowlegs & Tringa flavipes & 0 & 0 & 1 & 1 \\
\hline Merlin & Falco columbarius & 0 & 0 & 1 & 1 \\
\hline Northern Mockingbird & Mimus polyglottos & 1 & 0 & 0 & 1 \\
\hline Pectoral Sandpiper & Calidris melanotos & 1 & 0 & 0 & 1 \\
\hline Ring-necked Duck & Aythya collaris & 1 & 0 & 0 & 1 \\
\hline Sanderling & Calidris alba & 1 & 0 & 0 & 1 \\
\hline Spruce Grouse & Falcipennis canadensis & 1 & 0 & 0 & 1 \\
\hline Turkey Vulture & Cathartes aura & 1 & 0 & 0 & 1 \\
\hline White-breasted Nuthatch & Sitta carolinensis & 1 & 0 & 0 & 1 \\
\hline White-crowned Sparrow & Zonotrichia leucophrys & 1 & 0 & 0 & 1 \\
\hline
\end{tabular}




\section{References}

Acevedo-Charry, O. and T. M. Aide. 2019. Recovery of amphibian, reptile, bird and mammal diversity during secondary forest succession in the tropics. Oikos 128:1065-1078.

Alsila, T., M. Elo, T. Hakkari, and J. S. Kotiaho. 2021. Effects of habitat restoration on peatland bird communities. Restoration Ecology 29:e13304.

Andersen, R., C. Farrell, M. Graf, F. Muller, E. Calvar, P. Frankard, S. Caporn, and P. Anderson. 2017. An overview of the progress and challenges of peatland restoration in Western Europe. Restoration Ecology 25:271-282.

Brady, C. J. and R. A. Noske. 2010. Succession in bird and plant communities over a 24-year chronosequence of mine rehabilitation in the Australian monsoon tropics. Restoration Ecology 18:855-864.

Brewer, R. 1967. Bird populations of bogs. Wilson Bulletin 79:371-396.

Burnham, K. P. and D. R. Anderson. 2002. Model selection and multimodel inference: a practical information-theoretic approach (second edition), second edition. Springer-Verlag, New York, NY, USA.

Calmé, S. and A. Desrochers. 1999. Nested bird and micro-habitat assemblages in a peatland archipelago. Oecologia 118:361-370.

Calmé, S. and A. Desrochers. 2000. Biogeographic aspects of the distribution of bird species breeding in Québec's peatlands. Journal of Biogeography 27:725-732.

Calmé, S., A. Desrochers, and J.-P. L. Savard. 2002. Regional significance of peatlands for avifaunal diversity in southern Québec. Biological Conservation 107:273-281.

Chimner, R. A., D. J. Cooper, F. C. Wurster, and L. Rochefort. 2017. An overview of peatland restoration in North America: where are we after 25 years? Restoration Ecology 25:283-292.

Corbani, A. C., M.-H. Hachey, and A. Desrochers. 2014. Food provisioning and parental status in songbirds: can occupancy models be used to estimate nesting performance? PLoS ONE 9:e101765.

Cross, S. L., S. Tomlinson, M. D. Craig, K. W. Dixon, and P. W. Bateman. 2019. Overlooked and undervalued: the neglected role of fauna and a global bias in ecological restoration assessments. Pacific Conservation Biology 25:331-341.

CSPMA. 2014. CSPMA Industry Social Responsibility Report. Canadian Sphagnum Peat Moss Association, St. Albert, Alberta, Canada.

Desrochers, A., L. Rochefort, and J.-P. L. Savard. 1998. Avian recolonization of Eastern Canadian bogs after peat mining. Canadian Journal of Zoology 76:989-997.

Desrochers, A. and G. A. van Duinen. 2006. Peatland fauna. In R. K. Wieder and D. H. Vitt, editors, Boreal Peatland Ecosystems, pages 67-100. Springer-Verlag, Berlin, Germany.

Efron, B. 1982. The jackknife, the bootstrap, and other resampling plans. Society for Industrial and Applied Maths, Philadelphia, PA, USA. 
Erskine, A. J. 1977. Birds in boreal Canada: communications, densities, and adaptations. Report Series 41, Government of Canada, Canadian Wildlife Service.

ESRI. 2019. Esri ${ }^{\circledR}$ ArcMap 10.8.0.12790. Environmental Systems Research Institute, Inc., Redlands, CA, USA.

Famous, N. C., M. Spencer-Famous, J.-Y. Daigle, and J. J. Thibault. 1995. Coastal raised mire restoration: mosaic of peatland, salt marsh and minerotrophic wetlands for avian habitat enhancement. In B. D. Wheeler, S. C. Shaw, W. J. Fojt, and R. A. Robertson, editors, Restoration of temperate wetlands, pages 451-470. Wiley, New York, NY, USA.

Girard, M., C. Lavoie, and M. Thériault. 2002. The regeneration of a highly disturbed ecosystem: A mined peatland in southern Québec. Ecosystems 5:274-288.

González, E. and L. Rochefort. 2014. Drivers of success in 53 cutover bogs restored by a moss layer transfer technique. Ecological Engineering 68:279-290.

Gorham, E. 1990. Biotic impoverishment in northern peatlands. In G. M. Woodwell, editor, The Earth in transition, pages 65-98. Cambridge University Press, Cambridge, UK.

Gorham, E. and L. Rochefort. 2003. Peatland restoration: a brief assessment with special reference to Sphagnum bogs. Wetlands Ecology and Management 11:109-119.

Green, P. E. 1983. Natural revegetation of mined peatlands in northern Minnesota. M. sc., University of Minnesota.

Hapner, J. A., J. A. Reinartz, G. G. Fredlund, K. G. Leithoff, N. J. Cutright, and W. P. Mueller. 2011. Avian succession in small created and restored wetlands. Wetlands 31:1089-1102.

Hugron, S., M. Guêné-Nanchen, N. Roux, M.-C. LeBlanc, and L. Rochefort. 2020. Plant reintroduction in restored peatlands: 80transferred - Does the remaining 20 Global Ecology and Conservation 22:e01000.

Karofeld, E., L. Jarašius, A. Priede, and J. Sendžikaitè. 2017. On the after-use and restoration of abandoned extracted peatlands in the Baltic countries. Restoration Ecology 25:293-300.

Karofeld, E., M. Müür, and K. Vellak. 2016. Factors affecting re-vegetation dynamics of experimentally restored extracted peatland in Estonia. Environmental Science and Pollution Research 23:13706-13717.

Lavoie, C., P. Grosvernier, M. Girard, and K. Marcoux. 2003. Spontaneous revegetation of mined peatlands: an useful restoration tool? Wetlands Ecology and Management 11:97-107.

Lavoie, C. and A. Saint-Louis. 1999. The spread of gray birch (Betula populifolia) in eastern Quebec: landscape and historical considerations. Canadian Journal of Botany 77:859-868.

Legendre, P., M.-J. Fortin, and D. Borcard. 2015. Should the Mantel test be used in spatial analysis? Methods in Ecology and Evolution 6:1239-1247.

MacKenzie, D. I., J. D. Nichols, S. Lachman, S. Droege, A. Royle, and C. A. Langtimm. 2002. Estimating site occupancy rates when detection probabilities are less than one. Ecology 83:22482255. 
Mazerolle, M. J. 2020. AICcmodavg: Model selection and multimodel inference based on (Q)AIC(c). R package version 2.3-1.

Mazerolle, M. J., A. Desrochers, and L. Rochefort. 2005. Landscape characteristics influence pond occupancy by frogs after accounting for detectability. Ecological Applications 15:824-834.

Minayeva, T. Y., O. Bragg, and A. Sirin. 2017. Towards ecosystem-based restoration of peatland biodiversity. Mires and Peat 19:1-36.

Moreno-Mateos, D., M. E. Power, F. A. Comín, and R. Yockteng. 2012. Structural and Functional Loss in Restored Wetland Ecosystems. PLoS Biology 10:e1001247.

NABCI. 2019. The state of Canada's birds, 2019 (supplementary data). North American Bird Conservation Initiative and Environment and Climate Change Canada, Ottawa, ON, Canada.

Newman, M. E. 2005. Power laws, Pareto distributions and Zipf's law. Contemporary Physics 46:323-351.

Palmer, M. A., R. F. Ambrose, and N. L. Poff. 1997. Ecological theory and community restoration ecology. Restoration Ecology 5:291-300.

Pellerin, S. 2003. Des tourbières et des hommes. Le Naturaliste Canadien 127:18-23.

Poulin, M. and S. Pellerin. 2001. La conservation. In S. Payette and L. Rochefort, editors, Écologie des tourbières du Québec-Labrador, pages 505-518. Presses de l'Université Laval, Sainte-Foy, QC, Canada.

Poulin, M., S. Pellerin, J. Cimon-Morin, S. Lavallée, G. Courchesne, and Y. Tendland. 2016. Inefficacy of wetland legislation for conserving Quebec wetlands as revealed by mapping of recent disturbances. Wetlands Ecology and Management 24:651-665.

Poulin, M., L. Rochefort, F. Quinty, and C. Lavoie. 2005. Spontaneous revegetation of mined peatlands in eastern Canada. Canadian Journal of Botany 83:539-557.

Prach, K., G. Durigan, S. Fennessy, G. E. Overbeck, J. M. Torezan, and S. D. Murphy. 2019. A primer on choosing goals and indicators to evaluate ecological restoration success. Restoration Ecology 27:917-923.

Purre, A., M. Ilomets, L. Truus, R. Pajula, and K. Sepp. 2020. The effect of different treatments of moss layer transfer technique on plant functional types' biomass in revegetated milled peatlands. Restoration Ecology 28:1584-1595.

R Core Team. 2020. R: A Language and Environment for Statistical Computing. R Foundation for Statistical Computing, Vienna, Austria.

Rochefort, L. 2000. Sphagnum - A keystone genus in habitat restoration. Bryologist 103:503-508.

Rochefort, L., F. Isselin-Nondedeu, S. Boudreau, and M. Poulin. 2013. Comparing survey methods for monitoring vegetation change through time in a restored peatland. Wetlands Ecology and Management 21:71-85.

Rotenberry, J. T. 1985. The role of habitat in avian community composition: physiognomy or floristics? Oecologia 67:213-217. 
Ruiz-Jaen, M. C. and T. Mitchell Aide. 2005. Restoration success: how is it being measured? Restoration Ecology 13:569-577.

Smart, P. J., B. D. Wheeler, and A. J. Willis. 1989. Revegetation of peat excavation in a derelict raised bog. New Phytologist 111:733-748.

Soberón, J. and J. Llorente. 1993. The use of species accumulation functions for the prediction of species richness. Conservation Biology 7:480-488.

Sullivan, B., C. Wood, M. Iliff, R. Bonney, D. Fink, and S. Kelling. 2009. eBird: a citizen-based bird observation network in the biological sciences. Biological Conservation 142:2282-2292.

Sálek, M. 2012. Spontaneous succession on opencast mining sites: implications for bird biodiversity. Journal of Applied Ecology 49:1417-1425.

Ulrich, W., M. Ollik, and K. I. Ugland. 2010. A meta-analysis of species-abundance distributions. Oikos 119:1149-1155.

Wheeler, B. D. and S. C. Shaw. 1995. Restoration of damaged peatlands. HMSO, Department of the Environment, London, UK.

Wickham, H., M. Averick, J. Bryan, W. Chang, L. D. McGowan, R. François, G. Grolemund, A. Hayes, L. Henry, J. Hester, M. Kuhn, T. L. Pedersen, E. Miller, S. M. Bache, K. Müller, J. Ooms, D. Robinson, D. P. Seidel, V. Spinu, K. Takahashi, D. Vaughan, C. Wilke, K. Woo, and H. Yutani. 2019. Welcome to the tidyverse. Journal of Open Source Software 4:1686.

Wilson, J., W. H. 2020. Palm Warbler (Setophaga palmarum), version 1.0. In F. Poole, A., editor, Birds of the World. Cornell Lab of Ornithology, Ithaca, NY, USA.

Wilson, S. and E. Bayne. 2019. Songbird community response to regeneration of reclaimed wellsites in the boreal forest of Alberta. Journal of Ecoacoustics 3:1-11.

Young, T. P. 2000. Restoration ecology and conservation biology. Biological Conservation 92:73-83. 